\title{
КЛАСТЕРИЗАЦІЯ РИЗИКОВОЇ ПОВЕДІНКИ ПІДЛІТКІВ: АНАЛІЗ РЕЗУЛЬТАТІВ ДОСЛІДЖЕННЯ
}

УДК: 159.9 .07

\section{Рахімкулова Анастасія Станіславівна \\ Аспірант кафедри Клінічної психології ІІПО ОНУ ім. I.I. Мечнікова, м. Одеса (Украӥна); нейропсихо- лог, Центр дитячої та підліткової нейропсихологіï, м. Москва (Російська Федераиія)}

\begin{abstract}
Анотація. У статті представлено результати стосовно патернів кластеризації ризикової поведінки підлітків, щуо ми отримали при проведені дослідження по вивченню психологічних особливостей ризикової поведінки підлітків м. Одеси. Залучення підлітка до ризикової поведінки значно впливає на його емочійний стан, у тому числі схильність до депресії та тривожності, самооцінювання, сприйняття теперішнього та майбутнього, уразливість до стресу, здатність до соичальної взаємодії тощчо. Особливо турбує вчених взаємозв 'язок ризикової поведінки із суйчидальністю у підлітків. У разі якщчо підліток залучається до декількох видів ризикової поведінки, тобто ризикова поведінка кластеризується, негативний вплив на психосоматичне здоров'я підлітка критично збільшується. На базі статистичних спостережень висказується гіпотеза, за яким патерном можуть кластеризуватися різні види ризикової поведінки у підлітків.
\end{abstract}

Ключові слова: підлітки, психічне здоров'я, ризикова поведінка підлітків, кластеризачія ризикової поведінки.

Постановка проблеми. 32014 року ризикова поведінка (РП) підлітків була визнана ВООЗ як основна причина смертності і подальшої непрацездатності підлітків у віці 1118 років [12]. Деякими авторами навіть було запропоновано виділити РП в окремий синдром $[4,10]$. Серед видів РП, що найбільш загрожує здоров'ю, благополуччю та розвитку підлітків, автори виділяють: усі види поведін- ки, що пов'язані із заподіянням фізичного ушкодження (наприклад, насильство, самоушкоджуюча поведінка, суїцид); небезпечна сексуальна поведінка (яка може привести до незапланованої вагітності або зараженню ІПСШ, зокрема ВІЧ); зловживання ПАР, небезпечна екстремальна поведінка (у тому числі, небезпечне водіння); антисоціальна (делінквентна) поведінка; нездорова харчова поведінка та фі- 
зична пасивність. Особливо небезпечним для здоров'я і життя підлітків вважається поєднання декількох (не менше 4) видів РП, або, іншими словами, кластеризація ризикової поведінки [1-3, 6-8]. У той же час, у сучасній Україні ще мало досліджень, присвячених як питанням безпосередньо РП, так і аналізу причин і наслідків його кластеризації.

Аналіз останніх досліджень і публікацій. У сучасних теоріях ризикової поведінки, чому було присвячено декілька інших наших робіт, схильність підлітків до РП пояснюється 3 позицій нейропсихологічних (біологічних), соціальних і психологічних. Часто підіймається питання про чинники (фактори), що утримують підлітків від залученості в РП, і про чинники ризику, що провокують РП $[5,9]$. Багаточисельні роботи вказують на те, що чим раніше підліток починає РП, тим вище вірогідність, що до кінця свого підліткового віку він буде залучений не в 1-2, а в 6 і більше видів РП, і по мірі дорослішання число видів РП зростатиме $[4,7,11]$. По мірі залучення до РП, зростають і їі негативні наслідки, призводячи до того, що підлітки мають найвищий показник DALY у порівнянні із іншими віковими групами.

При вивченні кластеризації РП найбільш перспективним i, в той же час, найменш вивченим представляється пошук психологічних патернів (або моделей), за якими відбувається кластеризація, що і призвело до написання цієї статті.
Більшість авторів вказує на те, що залученість підлітків до ризикової поведінки починається із зловживання психоактивними речовинами $[4,6,7,10,11]$. І справді, алкоголізація та тютюнозалежність молоді, за деякими даними, приймає останніми роками характер епідемії $[10,12]$. Більш того, вчених турбує омолодження зловживання ПАР та тенденція до зловживання декількома видами ПАР, так звана полінаркоманія $[1,7,10]$. Однак, ми вважаємо що зловживання ПАР, як вид ризикової поведінки, не трапляється випадково, i вимагає певних психологічних причин для того, щоб підліток став залежним від регулярного споживання ПАР.

Те саме стосується і небезпечної сексуальної поведінки. У сучасному світовому просторі уяви про нормативний психосексуальний розвиток дещо змінюється, оскільки суттєво змінилася соціальна парадигма відносно дошлюбних сексуальних відносин. Підлітковий вік асоціюється із розквітанням сексуальності особистості і експериментування у цій сфері навіть заохочується. Як результат, початок сексуального життя у підлітковому віці не сприймається як порушення психосексуального розвитку, принаймні рядом вчених. А в тім, за кількома дослідженнями, початок статевого життя до завершення статевого розвинення провокує залучення до різних видів РП [4, 5, $8,11]$. Також, поширення ранніх вагітностей та захворювання ВІЧ серед підлітків створює реальну загрозу для їх подальшого життя та 
радикально змінює його [12].

Решта вивчених нами досліджень особливостей кластеризації ризикової поведінки присвячені вивченню кластеризації окремих видів ризикової поведінки із тими чи іншими [2-4, 6-9].

Формулювання цілей статті. Ми вважаємо, що хоча звернення підлітка до РП може розпочинатися як загальне підліткове експериментування із своїм оточенням та досвідом, РП має бути детермінується психологічними особливостями підлітка. Однак, регулярність РП призводить до їі кластеризації, тобто поєднання різних видів в однієї особи. У даній статі ми намагаємось проаналізувати отримані нами дані з метою з'ясувати, за якими патернами кластеризуються різні види РП.

Виклад основного матеріалу. У проведеному нами дослідженні РП взяли участь 603 підлітки 12-18 років, що навчаються у середньоосвітніх школах м. Одеси. Основний шар підлітків $(61 \%, 368$ дітей) регулярно практикували 2-3 види РП. Про свою незалученість або одноразове спробування РП повідомили близько 20\% дітей (122 підлітка), а про регулярну кластеризовану РП (більше 4 видів) - 19\% (115 чоловік). В принципі, це відповідає даним, презентованим іншими авторами у різних країнах $[2,3,8,11]$.

Подібний розподіл учасників дослідження дає деяким авторам обгрунтування для того, щоб говорити про нормативність РП в підлітковому віці. Ця ідея неодноразово зву- чала у різних дослідників $[1,6,9]$. Більш того, результати спостережень за іншими ссавцями також вказують на те, що при досягненні підліткового віку особини майже усіх видів ссавців демонструють те, що можна назвати ризиковою поведінкою. Проте на нашу думку, слід відрізняти ризикову поведінку як поведінку, що прямо чи опосередковано пов'язана із здоров'ям, благополуччям та здоровим розвитком особистості, від психологічних рис, що часто асоціюють із загальною схильністю здорової особистості до ризику: імпульсивність та потреба у нових враженнях. Отримані нами дані при порівнянні трьох груп підлітків із різними ступенями залученості до РП, свідчать про те, що ризикова поведінка, на відміну від схильності до ризику, не оказує ніяких позитивних впливів на розвиток підлітків.

До складу анкети було включено прямі загальні питання про особливості життя i умови мешкання дітей, питання про залученість в РП і ряд визнаних в світі і валідизованих в Україні шкал та методик.

Найпоширенішим видом РП серед підлітків в Україні виявилося зловживання ПАР. Лише 41,98\% (254 підлітки) повідомили, що ніколи не пробували алкоголь і 56,46\% (341 підлітки) стверджували, що ніколи не палили сигарети. 1 або кілька разів в місяць випивають 50,34\% підлітків, 6,77\% дітей вживають алкоголь 2-4 рази кожного тижня і майже $1 \%$ п'ють алкоголь кілька разів протягом 1 дня. 
Серед підлітків, що вживають алкоголь із різною частотою і інтенсивністю, переважають дівчатка, а серед підлітків, що ніколи не вживають алкоголь - хлопчики. Зловживання наркотичними засобами не поширене серед підлітків в Україні - регулярне вживання наркотиків визнали лише 1,16\% підлітків.

Рівень зловживання ПАР збільшується по мірі дорослішання підлітків. 61,90\% підлітків 12-13 років, що взяли участь в дослідженні, не вживають алкоголь, тоді як 48,28\% підлітків 14-15 і 61,04\%16-18 років вживають алкоголь 1-4 рази в місяць. Найбільший відсоток підлітків, що вживають алкоголь кілька разів на протяг кожного дня - 2,6\% - у підлітків 16-18 років, при чому 75\% 3 них - дівчатка.

Зловживання ПАР частіше всього кластеризується з порушеннями сексуальної поведінки $(\chi 2=66,798 ; \mathrm{p}=0,00001)$, пропуском школи $(\chi 2=20,388 ; \mathrm{p}=0,00001)$, інтернетомзалежністю $(\chi 2=20,196 ; p=0,0001)$, насильством $(\chi 2=14,078 ; p=0,0002)$, відсутністю занять спортом $(\chi 2=10,202 ; \mathrm{p}=0,001)$, агресивністю $(\chi 2=5,858 ; p=0,01)$. Найбільш небезпечним представляється нам висока міра взаємообумовленості зловживання ПАР у підлітків 3 самоповреждаючою поведінкою $(\chi 2=$ 22,583; $\mathrm{p}=0,00001)$ і суїцидальністю $(\chi 2=$ 19,5777; $\mathrm{p}=0,0001)$.

Друга за чисельністю група РП у нашому дослідженні - група підлітків, які віддають перевагу провокуючій екстремальній поведін- ці. Ці підлітки в два рази частіше - хлопчики у віковій групі 14-15 років. Засновники суїцидології (Е. Дюркгейм, Н. Фарберроу, Е. Шнейдман) часто асоціювали подібну провокуючу екстремальну поведінку з «прихованим суїцидом».

Провокуюча екстремальна поведінка кластеризується із забіякуватістю $\left(\chi^{2}=\right.$ $31,763 ; \mathrm{p}=0,00001)$, зловживанням алкоголем $(\chi 2=25,9888 ; \mathrm{p}=0,00001)$, наркотиками $(\chi 2=$ $23,796 ; \mathrm{p}=0,00001)$, насильством $(\chi 2=19,654$; $\mathrm{p}=0,00001)$, курінням $\left(\chi^{2}=16,884 ; \mathrm{p}=\right.$ 0,00001), раннім початком сексуального життя $(\chi 2=24,744 ; \mathrm{p}=0,00001)$, надлишком сексуальних партнерів $\left(\chi^{2}=11,500 ; \mathrm{p}=0,0007\right)$. Досить несподіваним було виявити зв'язок між таким невиправданим ризиком і переживанням фізичного $(\chi 2=3,958 ; p=0,04)$, сексуального $\left(\chi^{2}=4,696 ; \mathrm{p}=0,03\right)$ та інтернетнасильства ( $\chi 2=8,356 ; p=0,003)$. Підлітки, залучені в провокуючу екстремальну поведінку, мають високі показники самоповреждающего поведінки $(\chi 2=14,161 ; p=0,0002)$ i суїцидальної активності, в порівнянні із звичайними підлітками $(\chi 2=17,345 ; \mathrm{p}=0,0002)$.

Третя за чисельністю група РП в нашому дослідженні була група підлітків, із порушеннями харчової поведінки та відсутністю занять спортом. Зіставлення росту підлітків і їхньої ваги виявило 4,30\% підлітків, страждаючих предожирінням або ожирінням 1 ступені (індекс маси тіла понад 24,99) і 32,45\% дітей, що мають дефіцит маси тіла (індекс маси 
тіла нижче 18,5). Дівчатка в 1,3 рази рідше, ніж хлопчики страждають предожирінням і в 1,5 разу частіше - недоліком маси тіла.

Але із дорослішанням у підлітків спостерігається стійка тенденція до збільшення маси тіла - кількість дітей, страждаючих предожирінням, збільшується з 2,33\% в 12-13 років до 5,23\% в 16-18 років (у 2,3 разу). У той же самий час кількість дітей, що мають недостатню масу тіла падає з $53,49 \%$ в $12-13$ років до $22,88 \%$ в $16-18$ років (також в 2,3 разу).

Більшість підлітків регулярно займаються спортом впродовж останніх 6 місяців (369 чоловік, 60,99\% від всієї вибірки). Хоча порушення харчової поведінки можна спостерігати як у фізично активних, так і у фізично пасивних підлітків, відсоток підлітків з дефіцитом маси тіла і передожирінням вище серед фізично пасивних підлітків - 236 чоловік, або $39,01 \%$.

Відсутність фізичного навантаження окрім очевидних порушень харчової поведінки кластеризується з курінням ( $\chi 2=10,011$; $=0,001)$, зловживанням алкоголю $(\chi 2=9,090$; $\mathrm{p}=0,002)$, раннім початком сексуального життя $(\chi 2=8,240 ; \mathrm{p}=0,004)$, невикористанням засобів захисту при заняттях сексом $(\chi 2=$ $7,944 ; \mathrm{p}=0,004)$, інтернетом-залежністю $(\chi 2=$ $5,306 ; \mathrm{p}=0,02)$, пропуском школи $(\chi 2=4,411$; $\mathrm{p}=0,002)$. Саме серед підлітків, які не захоплені спортивною діяльністю, можна спостерігати найбільшу кількість підлітків 3 кластеризованою ризиковою поведінкою $(\chi 2=86,568$; $\mathrm{p}=0,00001)$.

Якщо група підлітків 3 порушеннями харчової поведінки і недоліком фізичної активності може викликати спори у різних авторів відносно права розглядатися як вигляд РП, то наступна за чисельністю група в нашому дослідженні- група підлітків з порушеннями сексуальної поведінки - спори не викликає.

22,72\% (137) підлітків відзначили, що вже мали сексуальний контакт, при чому $18,98 \% 3$ них не використали засобу захисту. Серед підлітків, що вже отримали сексуальний досвід 59,12\% мали на момент дослідження лише 1 сексуального партнера, 17,51\% двох партнерів, 12,4\% - три або чотирьох партнерів, а 10,21\% відзначили, що мали від 5 до 17 партнерів. Підлітки, що повідомили про велику кількість сексуальних партнерів, в основному хлопчики 16-18 років.

Ранній початок сексуального життя кластеризується 3 багатьма іншими видами ризикової поведінки: курінням $(\chi 2=77,148 ; \mathrm{p}$ $=0,00001)$, зловживанням алкоголем $(\chi 2=$ $39,083 ; \mathrm{p}=0,00001)$, наркотиками $\left(\chi^{2}=\right.$ $30,282 ; p=0,00001)$, їздою з нетверезим воді$\epsilon \mathrm{m}\left(\chi^{2}=11,091 ; \mathrm{p}=0,0009\right)$, відвідинами небезпечних місць $(\chi 2=7,349 ; \mathrm{p}=0,006)$, пропуском школи $(\chi 2=7,064 ; p=0,007)$, відсутністю занять спортом $(\chi 2=6,025 ; \mathrm{p}=0,01)$. Ранній початок сексуального життя і його порушення спричиняють за собою значні порушення харчової поведінки, особливо серед дівчаток $(\chi 2$ $=9,440 ; \mathrm{p}=0,008)$. 
Підлітки, що вже почали статеве життя, стають уразливими для самоушкоджуючої $(\chi 2=5,088 ; \mathrm{p}=0,02)$ і суїцидальної поведінки, особливо суїциїдальних спроб ( $\chi^{2}=22,478 ; \mathrm{p}$ $=0,00001)$.

П'ята група РП, вивчена нами, складалася $з$ дітей, що пережили фізичне, сексуальне або інтернет-насильство. Взагалі, підлітковий вік визначають як «сензитивний до насильства». За результатами нашого опитувальника 89,07\% підлітків міста Одеси не стикалися 3 фізичним, сексуальним або інтернет насильством. 0,99\% стикалися зі всіма згаданими видами насильства за останній рік. Найтривожнішим симптомом є та обставина, що жертви насильства 3 боку однолітків частенько не говорять про це нікому.

Про скоєне над ними фізичне насильство повідомили 3,65\% підлітків, про сексуальне - 2,49\% підлітків. Від інтернет-насильства постраждала практично в 3 рази більша кількість підлітків - 7,79\%. Серед жертв насильства очікувано більше дівчаток.

Діти, що пережили насильство, часто виявляються схильними до інших видів ризикової поведінки: зловживанню наркотиками $(\chi 2=55,230 ; \mathrm{p}=0,00001)$, алкоголем $(\chi 2=$ $10,442 ; \mathrm{p}=0,0001)$, курінням $(\chi 2=9,500 ; \mathrm{p}=$ 0,002), їздою 3 нетверезим водієм $(\chi 2=$ $16,090 ; \mathrm{p}=0,0001)$ і без шлему $(\chi 2=15,685 ; \mathrm{p}$ $=0,0001)$, зацепінгом $(\chi 2=11,584 ; \mathrm{p}=0,0007)$, раннім початком сексуального життя $(\chi 2=$ $5,696 ; p=0,01)$, надлишком сексуальних парт- нерів $(\chi 2=4,376 ; p=0,03)$. Серед підліткових жертв насильства особливо поширені самоушкоджуюча $\left(\chi^{2}=6,120 ; \mathrm{p}=0,01\right)$ і суїцидальна поведінка - думки $(\chi 2=26,003 ; \mathrm{p}=$ $0,00001)$, наміри ( $\chi 2=7,384 ; \mathrm{p}=0,006)$, спроби $\left(\chi^{2}=25,361 ; p=0,00001\right)$. Більш всього про смерть і можливий суїцид думають підлітки, що пережили інтернет насильство. Проте, найбільш високі показники суїцидальних намірів і планів спостерігалися у жертв сексуального насильства.

Остання виділена нами група РП - це група підлітків, що регулярно здійснюють самоушкодження. За статистикою ВIЗ самоушкодженням в світі займається 1-4\% населення, в основному підліткового віку [12]. Проте, отримані нами дані говорять про те, що порядку 10\% підлітків, що взяли участь в нашому дослідженні, пробували завдавати шкоди своєму фізичному тілу за допомогою гострих та колючих предметів, вогню і навіть наносили собі важкі травми.

Для підлітків, які постійно практикують самоушкоджуючу поведінку (більше 5 разів на момент дослідження), найпопулярнішим способом залишається різання зап'ясток, рук та інших частин тіла. Самоушкоджуюча поведінка значимо кластеризується з іншими видами ризикової поведінки, у тому числі: курінням $(\chi 2=30,395 ; \mathrm{p}=0,00001)$, зловживанням наркотиками $(\chi 2=18,134 ; \mathrm{p}=0,00001)$ i алкоголем $(\chi 2=6,324 ; \mathrm{p}=0,00001)$, провокуючою екстремальною поведінкою $\left(\chi^{2}=\right.$ 
$14,161 ; \mathrm{p}=0,0002)$, порушеннями сексуальної поведінки $(\chi 2=9,958 ; p=0,001)$. Серед підлітків, які наносять собі фізичні пошкодження, багато жертв сексуального $(\chi 2=5,164 ; \mathrm{p}=$ $0,02)$ і інтернет $(\chi 2=3,925 ; p=0,05)$ насильства.

Для зведення всієї безлічі отриманих даних про кластеризацію РП, ми провели кластерний аналіз, який дозволив побудувати наступну дендрограму по методу середнього зв'язку з використанням евклідової відстані. Відстань між об'єктом 1 (насильство) і об'єктом 2 (сексуальна поведінка) - 19,49359, між об'єктом 2 і об'єктом 3 (зловживання ПАР) 21,67375, об'єктом 3 і об'єктом 4 (провокуюча екстремальна поведінка) - 27,9566) (Рисунок 1):

Таким чином, отримані дані дійсно сві- дчать про те, що легко спостережувані види РП, такі як зловживання ПАР та небезпечна сексуальна поведінка, не є причиною, за якою підлітки вдаються до регулярної практики РП та пізніше приходять до кластеризації різних видів РП.

\section{Висновки 3 дослідження та перспек-} тиви подальших розвідок. Ми припускаємо, що зіткнення 3 насильством в дитинстві чи підлітковому віці провокує створення такого психологічного стану, який детермінує подальшу залученість підлітків до кластеризованої РП. При цьому, скоєне насильство може мати як реальну форму (у разі фізичного чи сексуального насильства), так і віртуальну форму (у разі інтернет-насильства). Кількість часу, що підлітки проводять онлайн, спілкуючись один 3 одним та інколи із незнайомцями, у поєднан-

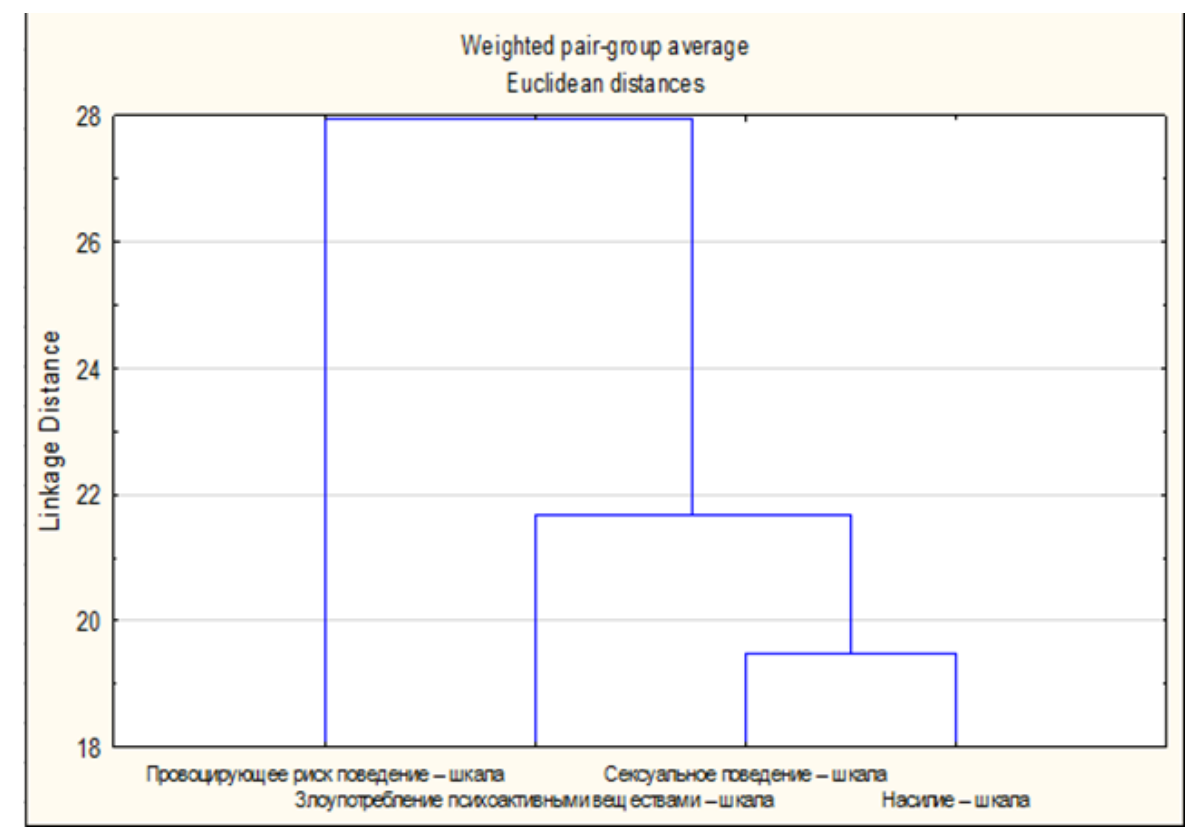

Рис. 1. Дендрограма кластеризації видів ризикової поведінки 
ні із розповсюдженістю інтернет-насильства у порівнянні з іншими видами насильства, має викликати підвищену турботу з боку спеціалістів.

Особа підлітка, що піддався насильству, часто емоційно нестійка і не має розвиненого вольового компоненту. Невідпрацьована психічна травма закріплює у структурі особистості підлітка примітивні та непродуктивні копінг-механізми, що додатково робить його уразливим до стресу, знижуючи його поріг стрес-резистентності. Значно страждає самооцінка. Незадоволеність життям, нездатність до адекватної соціальної адаптації, неспроможність сприйняти своє майбутнє у позитивному ключі - це лише мала дещиця переживань, що долають підлітки, які були об'єктами насильства. Комплекс постійних негативних переживань у купі із ушкодженою самооцінкою роблять підлітка уразливим і провокують подальший розвиток співвідносних компенсаторних психологічних механізмів. Пубертатний період у таких умовах набуває форми дисгармонійного психосексуального розвитку, що виявляється в небезпечній сексуальній поведінці підлітків: сексуальне життя починається рано, підліток намагається міняти багато партнерів, не використовує засобів захисту і контрацепції.

Загальновідомо, що підлітковий вік $\epsilon$ періодом у житті особистості, коли гормональний та фізіологічний розвиток протікають у найбурхливішій формі, особливо після періо- ду дитинства, коли гормони здебільшого знаходяться у латентній стадії. Однак, підлітковий вік не $є$ піком розвиненої сексуальності. Ми розділяємо гіпотезу, що коли підліток прагне сексуальної близькості, він насправді прагне близькості емоційної. Оскільки його власний емоційний стан охоплений негативними переживаннями, самооцінка ушкоджена, розвинені продуктивні копінг-механізми відсутні, сексуальне життя, навіть із різними партнерами та без дотримання правил безпеки, не приводить до бажаного результату. Подібний поведінковий кластер провокує зловживання психоактивними речовинами, як доступний засіб ігнорування свого стану та реальності.

Алкоголізація надає емоційної компенсації лише тимчасово. На нашу думку, викликане таким чином зловживання ПАР може приводити до полінаркоманії підлітків, коли 1 виду ПАР швидко стає недостатньо. Якщо більшість підлітків вживає ПАР як один із варіантів експериментування або вживання заради соціальної вигоди, то вживання ПАР підлітками із кластеризованою РП швидко стає звичним і залежним. Чим активніше підлітки зловживають ПАР, тим більше їх тормозний вплив на нервову систему. Як наступний етап кластеризації, підлітки звертаються до провокуючої екстремальної поведінки, яка може бути небезпечною як для їх психічного, так і для їх соматичного здоров'я, а інколи і життя. 
Ми вважаємо, що було б доцільно робити подальші дослідження патернів кластеризації ризикової поведінки.

\section{Перелік використаних джерел:}

1. Biglan A., Brennan P.A., Foster S.L., Holder H. Helping Adolescents At Risk: Prevention of Multiple Problem Behaviors. - London, UK: The Guildford Press; 2004.

2. Brooks $F$. Adolescent multiple risk behaviour: an asset approach to the role of family, school and community. // Journal of Public Health. - 2012. - V. 34(S1). - P. 48-56.

3. Burke V., Milligan R.A.K., Beilin L.J. Clustering of health-related behaviors among 18-year-old Australians. // Preventive Medicine. - 1997. - V.26. - P.724-733.

4. DuRant R.H., Smith J.A., Kreiter S.R., Krowchuk D.P. The relationship between early age of onset of initial substance use and engaging in multiple health risk behaviours among young adolescents. // Archives of Pediatric and Adolescent Medicine. - 1999. - V.153. P.286-291.

5. Harel-Fisch Y., Abdeen Z., Walsh S.D., Radwan Q., Fogel-Grinvald H. Multiple risk behaviors and suicidal ideation and behavior among Israeli and Palestinian adolescents.//Social Sciences and Medicine. - 2012. - V.75 (1). - P. 98-108.

6. Kipping R. R., Campbell R.M., MacArthur G.J., Gunnell D.J., Hickman M. Multiple risk behaviour in adolescence.// Journal of Public Health. - 2003. - V.34(1). - P. i1-i2.

7. Spring B., Moller A.C., Coons M.J. Multiple health behaviours: overview and implications.// Journal of Public Health. - 2013. - V. 34(1). - P. 3-10.

8. Sychareun V., Thomsen S., Faxelid E. Concurrent multiple health risk behaviors among adolescents in Luangnamtha province, Lao PDR. // BMC Public Health. 2011. - V(13). - P.24-29.

9. Terzian M. A., Andrews K.M., Moore, K.A. Preventing Multiple Risky Behaviors: An Updated Framework for Policy and Practice. - Washington DC: Child Trends, 2011.
10. The relationship between early age of onset of initial substance use and engaging in multiple health risk behaviours among young adolescents. / DuRant R.H. et al. //Archives of Pediatriac and Adolescent Medicine. 1999. - V.153. - P. 286-291.

11. Van Nieuwenhuijzen M., Junger M., Velderman M.K. Clustering of health-compromising behaviour and delinquency in adolescents and adults in the Dutch population.// Preventive Medicine. - 2009. - V.48. - P.572578.

12. WHO draft health indicators for adolescents: Department of Maternal, Newborn, Child and Adolescent Health. - Geneva, World Health Organization, 2014.

\section{References (Transliteration):}

1. Biglan A., Brennan P.A., Foster S.L., Holder H. Helping Adolescents At Risk: Prevention of Multiple Problem Behaviors. - London, UK: The Guildford Press; 2004.

2. Brooks F. Adolescent multiple risk behaviour: an asset approach to the role of family, school and community. // Journal of Public Health. - 2012. - V. 34(S1). - P. 48-56.

3. Burke V., Milligan R.A.K., Beilin L.J. Clustering of health-related behaviors among 18-year-old Australians. // Preventive Medicine. - 1997. - V.26. - P.724-733.

4. DuRant R. H., Smith J.A., Kreiter S.R., Krowchuk D.P. The relationship between early age of onset of initial substance use and engaging in multiple health risk behaviours among young adolescents. // Archives of Pediatric and Adolescent Medicine. - 1999. - V.153. P.286-291.

5. Harel-Fisch Y., Abdeen Z., Walsh S.D., Radwan Q., Fogel-Grinvald H. Multiple risk behaviors and suicidal ideation and behavior among Israeli and Palestinian adolescents.//Social Sciences and Medicine. - 2012. - V.75 (1). - P. 98-108.

6. Kipping R. R., Campbell R.M., MacArthur G.J., Gunnell D.J., Hickman M. Multiple risk behaviour in adolescence.// Journal of Public Health. - 2003. - V.34(1). - P. i1-i2.

7. Spring B., Moller A.C., Coons M.J. Multiple health 
behaviours: overview and implications.// Journal of Public Health. - 2013. - V. 34(1). - P. 3-10.

8. Sychareun V., Thomsen S., Faxelid E. Concurrent multiple health risk behaviors among adolescents in Luangnamtha province, Lao PDR. // BMC Public Health. 2011. - V(13). - P.24-29.

9. Terzian M. A., Andrews K.M., Moore, K.A. Preventing Multiple Risky Behaviors: An Updated Framework for Policy and Practice. - Washington DC: Child Trends, 2011. 10. The relationship between early age of onset of initial substance use and engaging in multiple health risk behaviours among young adolescents. / DuRant R.H. et al. //Archives of Pediatriac and Adolescent Medicine. 1999. - V.153. - P. 286-291.

11. Van Nieuwenhuijzen M., Junger M., Velderman M.K. Clustering of health-compromising behaviour and delinquency in adolescents and adults in the Dutch population.// Preventive Medicine. - 2009. - V.48. - P.572578.

12. WHO draft health indicators for adolescents: Department of Maternal, Newborn, Child and Adolescent Health. - Geneva, World Health Organization, 2014.

\section{Rakhimkulova Anastasiya}

PhD student at Odessa State University after I.I. Mechnikov, Clinical Phsychology Department; neuropsychologist, Child and Adolescent Neuropsychology Centre, Moscow (Russian Federation)

\section{CLUSTERING PATTERN OFADOLESCENT RISKY BEHAVIOR: RESEARCH RESULTS ANALYSIS}

\author{
ABSTRACT \\ Negative outcomes of risky behavior in- \\ volvement influence multiple spheres of adoles- \\ cent lives. When a teenager takes on several types \\ of risky behavior at the same time, or in other \\ words, when his or her risky behavior clusters, \\ the adolescent becomes subject to even harsher
}

unfavorable impacts. We believe that trying out some risky behavior can start as typical teenage experimenting with the environment and self. However, nailing down on risky behavior and especially its clustering can only be possible if determined by some specific psychological complex within adolescent personality structure.

The article presents results of the study of risky behavior prevalence and psychological specifications of Ukrainian teenage schoolchildren of 12-18 years of age. The focus of the study spots types of risky behavior associated with possible negative outcomes for teenage health and life: substance abuse, unhealthy sexual behavior, violence, extreme sports, internet addiction. Though there is a number of studies of multiple risky behaviors, we failed to find ones that would examine the patterns of risky behavior clustering.

For each type of risky behavior - substance abuse, extreme risky behavior, food disorders, unhealthy sexual behavior, violence and self-harming behavior - the data is provided on how it clusters with other risky behaviors and psychological features of adolescents. Almost all types of risky behavior were found to cluster with self-harming and suicidal behavior.

The article renders results of the cluster analysis, which allowed us to compose a hypothesis of how risky behaviors actually get clustered during adolescence.

According to data obtained we believe that risky behavior involvement is provoked by certain psychological states caused by facing vio- 
lence during childhood and early adulthood. As a result, the psychosexual development follows a disharmonic pattern and the susceptibility to early substance abuse is created.

Whether the violence faced was real (physical or sexual), or virtual (when communicating in the Internet), it led to settling emotional instability and lack of will-power. The suffered trauma anchors primitive and unproductive coping strategies, making and adolescent vulnerable to stressful life events. Adolescent's self-attitude is also tampered. Life dissatisfaction, inability to adapt within the community, negative future perception - are just a few negative aspects that override adolescents with risky behavior.

Key words: adolescence, multiple risky behaviors, health compromising behaviors, risky behavior clusterization, patterns of clustering of risky behaviors.

\section{Рахимкулова Анастасия Станиславовна}

Аспирант кафедры Клинической психологии ИИПО ОНУ им. И.И. Мечникова, г. Одесса (Украина); нейропсихолог, Центр детской и подростковой нейропсихологии, г. Москва (Российская Федеращия)

\section{КЛАСТЕРИЗАЦИЯ РИСКОВОГО ПОВЕДЕНИЯ ПОДРОСТКОВ: АНАЛИЗ РЕЗУЛЬТАТОА ИССЛЕДОВАНИЯ}

Негативные последствия вовлеченности в рисковое поведение оказывают влияние на различные сферы жизни подростков. При увлечении несколькими видами рискового поведения одновременно, или другими словами, в случае кластеризации рискового поведения, подросток оказывается подверженным еще большему негативному влиянию. Мы считаем, что увлечение рисковым поведением может начаться как обычное подростковое экспериментирование с различными видами опытов и переживаний. Но закрепление тенденции к рисковому поведению и, тем более, его дальнейшей кластеризации обусловлено наличием некоего психологического комплекса в структуре личности подростка.

В статье представлены результаты исследования рискового поведения подростков 12-18 лет, учащихся общеобразовательных школ г. Одессы, Украина. Исследовались виды рискового поведения, чаще других ассоциированные с возможным неблагоприятным исходом для здоровья и жизни подростков. Для каждого вида рискового поведения представлены данные о его сочетании с другими видами. Также представлены результаты кластерного анализа, позволяющие высказать гипотезу о формировании возможной модели кластеризации рискового поведения подростков.

Ключевые слова: подростковый возраст, рисковое поведение подростков, кластеризация рискового поведения, модель кластеризации рискового поведения.

Дата отримання статті: 15.04 .2017 Дата рекомендації до друку: 14.05.2017 